\title{
SOME ASPECTS OF REFORM AND CHANGE IN THE SYSTEM OF SECONDARY MUSIC SCHOOLS - ANALYSIS OF RELEVANT LITERATURE
}

\author{
UDC $[373.54: 78]: 37.014 .3$
}

\section{Marija R. Marković, Anastasija S. Mamutović, Zorica Č. Stanisavljević Petrović}

University of Niš, Faculty of Philosophy, Niš, Republic of Serbia

\begin{abstract}
The paper debates some aspects of reform and change in secondary music education. The reforms in secondary music education are in line with the general tendencies in the school system in Serbia. Accordingly, the paper discusses the leading aspects of the changes in the secondary music schools and their alignment with similar schools in the European educational system.

The main objective of this theoretical research is to identify significant aspects of changes related to curriculum change and innovation in content - textbooks, and the assessment process. The paper uses a qualitative approach, based on an analysis of selected research studies published after 2001. They cover key topics related to changes in secondary music schools. In spite of the fact that there are few research papers in our region that deal with the implications of the reform in the secondary music education system, based on the analysis of the available papers we can conclude, that there are steps to meet the planned changes.
\end{abstract}

Key words: music schools, secondary education, reforms, curricula, innovation, working methods, assessment

\section{INTRODUCTION}

Significant reforms at all levels of education in the school system of Serbia have been demanded since 2000. The first steps were taken as a beginning of changing the school system in Serbia and its harmonization with the educational systems of developed countries. During this period, the first ideas emerged and were developed as solutions for overcoming the established and traditional patterns of school work and introducing a

Received March 23, 2020 / Accepted April 26, 2020

Corresponding author: Marija Marković

University of Niš, Faculty of Philosophy

E-mail: marija.markovic@filfak.ni.ac.rs 
qualitatively different approach in education that will develop the quality system and enable the availability and right to education to all interested stakeholders.

In line with such tendencies, considerable attention has been paid to formal education institutions, that is, schools as institutions primarily intended to pursue the process of pedagogocal and educational work. Accordingly, there are first steps in the changes at the level of primary education, as well as in schools as institutions where compulsory primary education is implemented. At the same time, the very concept of change in secondary education is underway, both in the system of general education schools, and in the system of vocational education schools. In order to ensure the implementation of reform measures in the relevant ministries in the Republic of Serbia, relevant programs and legal documents were adopted. In the context we should mention the Strategy for the Development of Education in Serbia until 2020 [1], the Law on Fundamentals of the Education System [2] and The Strategy for the Development of Vocational Education in the Republic of Serbia [3].

These and other relevant documents set out the goals and directions for the development of the education system in Serbia over the coming period. Along with the implementation of the reform changes, which was very complex and accompanied by numerous problems, open questions and dilemmas, there was a need for adequate monitoring and determination of the results achieved in the field of training-educational practice at all levels, including the level of secondary schools. In this context, the main part of this paper is dedicated to changes in secondary music education, with the aim of finding, through the analysis of available research studies, some conclusions about the implementation of reform steps in secondary music schools in our country.

\section{BASIC DiRECTIONS FOR SECONDARY VocATIONAL EDUCATION EEFORM}

The general objectives of the reform of the vocational secondary education are based on the general principles of change in the educational system. Considerable attention has been paid to 'democratization', which is a central process in reform that ensures the active involvement of all actors directly interested in changing secondary education [4]. A central issue, related to the democratization of secondary education, is the availability of providing equal opportunities for young people and adults for the acquisition of professional competences and lifelong education. The process of democratization in the modern school is also directed towards establishing and developing quality relations with the immediate local environment in terms of cooperating with the local social environment whose resources can influence the acquisition of qualitative knowledge and skills, i.e the competences that will enable students to integrate adequately into the environment [5].

The second important direction of the reform is decentralization at the level of secondary vocational education. This addresses school management issues and in the context, the reform requests closer determination of regional responsibility. They require the involvement of local government in developing quality and quantity in schools. This provides a possibility for the local community to be involved in the creation and implementation of school programs according to the specific needs that it has. Wider involvement of the local community creates a greater opportunity for the alignment of school needs and the surroundings, the decentralization of enrollment policies, and training staff for whom there is a real need in a given context. 
The next objective of secondary education reform is to demonopolize education and to cover the relationship between private and public schools, that is, the private and public sectors in education. Therefore, a special emphasis on the issues of standards in vocational education, the establishment of new schools, investment of foreign capital in company education, etc. are emphasized. Accordingly, the need to redefine and innovate a programme content in order to develop and improve quality is emphasized. In this context, demonopolitization of education is an expression of the desire to conform to European standards and to create a single European space for education [6].

In accordance with the previously defined goals, there is a need for the diversification of institutional forms and models in terms of adequate organization of vocational secondary schools. As a result, diversification emerges as one of the key goals of reforming vocational secondary education. Diversification at the internal level of secondary vocational education encompasses the level of curricula, educational contents and teaching methods. In this context, it tends to align with the nomenclature of occupations at national level and to redefine the structure of educational profiles. It emphasizes the importance of flexibility of the internal structure, and opens the space for the introduction of different forms of planning in accordance with the educational profiles and needs of the local community. From a pedagogical point of view, diversification of the curricula provides new opportunities for innovation in the education process at the level of secondary vocational schools, resulting in a positive effect on improving the quality of the teaching process.

In order to ensure the development of schools and the improvement of their quality, changes in the internal organization of the school are important. Among them, the special goal of the reform is the professionalization of the work of teachers and assistants. Innovation and improvement of the quality of teaching at the secondary education level depends to a large extent on the teachers themselves, on their competences, as well as the professional development system. In this context, the reform process emphasizes the need for change in initial teacher education, especially given the traditional education of secondary vocational school teachers so far. Vocational education comprises a wide variety of professional staff, which, in accordance with traditional education, are not sufficiently prepared in the field of pedagogical, psychological and andragogical competences. Accordingly, the first reform documents underline the need for adequate teacher competencies for school work [7]. Namely, the starting point is that professionalization of work of teachers and associates in secondary vocational education should include continuous training in the field of vocational and didactic - methodological education, capacity for team work, development of certain skills, as well as other forms of training.

The defined reform goals determined changes at the level of vocational secondary education. Significant support for the aforementioned reform directions was provided by the Law on Fundamentals of the Education System, which was adopted in 2009 [2], and included secondary education. According to this document, secondary schools are divided into general, vocational, and art schools [2]. While general education schools provide students with general education and preparation for the next levels of education, vocational secondary schools aim at vocational training for a particular profession. 


\section{Music SCHOOLS In THE SECONDARY EdUCATION System}

The work of secondary schools in the Republic of Serbia is defined in accordance with the Law of Secondary Education [8]. This document defines the work of secondary art schools belonging to the secondary education system. Article 4 of this Law states that "general art education and training shall be obtained at an art school for a four-year period, for the pursuit of the profession of appropriate occupation and for the continuation of education in higher education institutions [8, Article 4]. Within the art schools, work is being done with especially gifted students within the music, ballet and art schools of the fine arts. This creates opportunities for inclusive education in our country as an important aspect of the reform processes in education. The importance of realizing inclusive education in our country, the importance of developing teaching competences for inclusive education, as well as the possibilities of realizing the concept of inclusive education in schools are pointed out by numerous authors [eg. 9, 10, 11, 12]. Accordingly, specific, teaching competences in the area of secondary music education have been determined for performing music education activities.

Secondary music schools belong to art schools which implement "general and artistic education for four years for the pursuit of the profession and occupation in higher education institutions" [8, Article 4]. The importance of music schools is also reflected in the fact that it contributes to the culture of the city, independently or in cooperation with cultural institutions and the public media. Celebrations of school and public holidays, events, various performances, exhibitions, competitions and various other cultural activities organized not only in schools, but also in agreement with the local self-government in various cultural institutions, cannot be imagined without the participation of music school students, whether in the form of individual, group (chamber ensembles) or collective performances (school orchestra and choir).

Legal and program documents, above all the Statute of the school itself, determine the activity and organization of work of secondary music schools. An important task of the school is to provide all students with qualitative education and adequate development of competences in the field of music education [13]. Moreover, the School Statute defines other important issues related to the activity of the institution itself. For example, the Statute of the Music School in Niš [14] states that the main activity of a secondary music school is an educational activity, which the school can perform independently or in cooperation with other organizations and institutions. Educational work includes teaching and other forms of educational work with students with whom the school program is completed and the prescribed goals, outcomes and standards of achievement are realized. To implement the teaching process, textbooks and other teaching aids are used at the school, which are approved by the Minister of Education at the proposal of the National Education Council.

The educational-pedagogical activity is the basic activity of the secondary music school, which the school can perform independently or in cooperation with other organizations and institutions. In addition, the music school can perform an expanded activity: providing services, sales and other activities that promote or contribute to a more rational and qualitative education and upbringing, the implementation of training programs [14, Article 38]. The activity of the music school is performed in accordance with the Constitution of the Republic of Serbia [15], the Law on Fundamentals of the Education System [2] and the Statute of the school [14] itself. Currently there are 32 secondary music schools active in the Republic of Serbia. Of these, the School of Music 
Talents in Ćuprija should be singled out, with a unique curriculum of ten years (primary six years and secondary music education - four years).

In this school, the programs are tailored to above-average talented children who will be professionally involved in music. The school teaches only one course, the string section (instruments: violin, viola, cello and double bass) and is sponsored by the Faculty of Music in Belgrade. Students are provided with home accommodation within the school itself. In addition to individual teaching, just like with standard music schools, organization of teaching theoretical and general subjects is designed for smaller groups of students.

Table 1 Overview of Music High School Departments and educational profiles

\begin{tabular}{ll}
\hline Department & Educational Profile \\
\hline Vocal - Instrumental Department & Music Artist - Classical music \\
Jazz Department & Music Artist - Jazz music \\
Department of Music Theories & Music Associate - Theorist \\
Department of Traditional Music & Music Artist - Traditional music \\
Department of Church Music & Music Artist - Church music \\
Department for Early Music (Elective Department) & Music Artist - Early music \\
Department for Music Production and Sound Recording & Sound Designer \\
\hline
\end{tabular}

Table 1 evinces departments in music schools and educational profiles [16]. The main subject at the vocal-instrumental department is the Instrument (string instruments: violin, viola, cello, double bass; wind instruments: flute, oboe, clarinet, saxophone, bassoon, horn, trumpet, trombone, tube; percussion, harp, piano, organ, accordion, guitar, tambourine, mandolin, cymbal, zither) or Solo singing. The main subject at the Jazz department is Instrument (guitar, double bass, violin, bass, piano, keyboards and synthesizer, saxophone and clarinet, trumpet, trombone, jazz drums) or jazz singing. The main subject at the department of Music Theories is Solfeggio. In the Department of Traditional Music the main subject is Traditional Serbian Singing or Playing. In the Church Music section, is Church chanting with the typist. The department of early music is an elective section and must be studied at the same time with another compulsory department in the Secondary School of Music. The main subject is Instrument (string instruments, lute, renaissance harp, harpsichord, organ, wind instruments) or early singing. At the Department of Music Production and Sound Recording, the main subject is Sound and Music Process Technology, MIDI [16].

The entrance exam for the secondary music schools is taken in the June examination period, before enrollment in the first grade. If some candidates have not completed regular elementary education and have completed elementary music schools, they may enroll in secondary music schools where they attend vocational classes. Schools can check psychophysical prerequisites for dealing with music. In addition to the entrance exam, the exams conducted in secondary school music are: annual, class grade, corrective and graduation ones.

According to Hebib [17], the teaching process based on the curriculum is the process by which the basic function of the school and its activity is realized. However, in addition to teaching, other extracurricular activities are also implemented in the school. They can be implemented in collaboration with individuals or institutions interested in school work, in several stages: programming, implementation and evaluation. These processes are interconnected. It makes the planned contents of the program and envisaged methods of their realization subject to evaluation of the outcomes and goals of the educational process. 
The curriculum is divided into the following groups:

- Group A - General subjects

- Group B - Professional courses (theory, practice, practical training)

- Optional courses

- Compulsory extracurricular activities (in each class additional work 30-70 hours per year, internal classes 2 hours per year, public classes and concerts with one hour per year)

- Optional extracurricular activities (excursion in each class, one competition per year, seminars lasting up to 7 non-teaching days, camps up to 15 non-teaching days and other activities lasting up to 3 non-teaching days).

According to the Official Gazette [16], because of the specific nature of educationalpedagogical work, teaching in music schools is realized as individual, in a group and in a class. Individual instruction is represented in all major subjects, Comparative Piano, Piano and General Bass. Group classes are conducted with 2, 3, 8 or 15 students, depending on the group of subjects. Smaller groups of students are envisioned for smaller ensembles, playing scores, sheet music reading, concerts, and Chamber Music, while all professional theoretical subjects are heard in a group of 8 students. Other theoretical subjects can be heard in larger groups of 15 students. It is only the academic course choir that is collective, as it unites students of all classes and all departments [16].

The task of teaching in secondary music schools is, first and foremost, to cherish and accept cultural heritage and universal cultural and artistic values. In addition, an important task is the development of musical taste and instrumental performing skills. Students develop a sense of collective music while working in smaller groups such as chamber music and larger groups such as choir and orchestra. Moreover, learning about history, theory, composition and traditional musical folklore contributes to developing the individual creativity of students and raising the overall cultural and educational level of their environment.

\section{RESEARCH ON REFORM CHANGES OF SECONDARY MUSIC EDUCATION}

Changes in the Serbian school system in research studies are mainly aimed at examining the success of reform and their implementation in practice. A more complete account of the implementation of school reforms can be found in studies relating to the analysis of the current state and further directions of development [18]. The article entitled School System of Serbia - State and Trends in Development, by E. Hebib and V. Spasenović [18], analyzes the basics, course and effects of reform processes in education that have taken place since 2000. Some authors point out that the reform of the school system was accompanied by various difficulties and obstacles, among which there was a change of government from 2000 to 2010, which directly influenced the implementation of reform solutions and caused discontinuity in the implementation of the reform [19].

In contrast to the general approach to the reform of the school system, a much smaller number of research papers deals with the analysis of reform steps at different levels of the system. There seems to be even less work when it comes to aspects of reform within particular types of schools, such as secondary music schools. Although there are hardly any research papers, some authors point to the importance of pedagogical research in music teaching [20]. 
However, on the basis of the available papers, it can be stated that some authors have devoted themselves to the research of some topics relevant to the reform of secondary music education, among which there are topics related to changes in curricula, topics related to teaching, textbooks and teaching aids, topics related to the assessment process and student personality, etc.

In the research papers relating to reform efforts in music education, considerable attention is paid to changes in curricula. Stojanović, D. [21] emphasizes the need for changes in curricula in secondary music education within the course Contrapunt. In her paper, the author has been following the changes that have occurred in the curricula since 1965. The author gives a critical review of the earlier plans and programs within the subject, emphasizing that nothing has changed in the field for nearly 20 years. In this context, D. Stojanovic raises the question: Are there changes necessary and needed today? Referring to the reform that began in 2001, she stresses that, unlike higher music education, the reform has not yet been fully implemented at the secondary school level. Accordingly, she states that deeper changes are needed and that "the teaching of 'counterpoint' must be adapted to the needs of the profession, both in the number of classes and in the content" [21, p. 11] and rightly points out that reform in music education must first be based on empirical research.

In order to make education at the secondary level of music more qualitative, changes in the education of music school teachers themselves are necessary, that is, modification of the program, especially when it comes to the methodology of theoretical subjects [22]. In this context, it is rightly stated that programs of theoretical subjects should qualify the future teachers in secondary music schools for the planned, practical delivery of teaching while stimulating creative potential. That is why future teachers are expected to have developed critical thinking and to be well aware of the broad issues of music pedagogy. However, the authors rightly state that each document, and therefore the curriculum, is subject to change and that changes are necessary in accordance with the general tendencies in the broader social context and with the needs of an educated music professional. Accordingly, change is necessary, though it must be borne in mind that it is a process that is difficult to determine in time and to determine the degree of its acceptance in real practice. Hence, the authors propose to change the curriculum of the methodology of teaching theoretical subjects in two basic directions: the first is a general direction that starts from the redistribution of teaching theoretical subjects and the second one, a more specific direction, is related to the introduction of a different medium into the teaching process: training future teachers for an organized, thoughtful, practical teaching, developing an interdisciplinary approach, etc.

Issues related to contemporary teaching in secondary music schools are also a subject of interest for researchers. In the paper entitled "Problems of Contemporary Teaching in Secondary Music School" [23], the authors address issues related to methods of teaching theoretical subjects, their correlation, as well as their connection with music publishing. Based on the data obtained from the research, they concluded that a greater interconnection of theoretical subjects, above all, Harmony, Counterpoint and Musical Forms, was needed, while correlation of theoretical and performing subjects indicates a dominant problem - lack of teaching practice. In addition, the research results indicate that the teaching and learning process lacks the aesthetic experience of the written assignment, that is, the ability to distinguish between an accurately written assignment and an entirely beautiful and harmonious musical work written in the style of Classicism, Renaissance or Baroque. The interviewed students particularly showed an interest in contemporary artistic and popular music and a desire to incorporate their favorite musical directions into school practice [23, pp. 162-163]. 
Quiet a few research papers in the field of music education in secondary music schools are devoted to students performance as well as assessment. The author's interest in these issues is also present in the period before the reform efforts in secondary music education, so that works can be found dealing with student motivation [24], student success in learning music [25], and similar topics are present even after the introduction of refom changes [26, 27, 28, 29].

Closely related to the issue of student performance is the issue of assessment, as well as the monitoring and progress of students. In this context, there is no doubt that in the assessment it is necessary to respect the individual differences among students [30]. It is of particular importance for music education, because it is about gifted and creative students. In addition, other factors, especially those that are relevant to students themselves, are important in the assessment process. Accordingly, authors such as Stojanović, Nagorni Petrov and Zdravić Mihailović [31] argue that a holistic approach to student assessment in secondary and higher music education is important. Specifically, they cite the need to develop a holistic approach in the assessment process, according to which it is important to consider the personality of the student and the student as a whole, with all potentials and capacities, but also weaknesses. In this regard, it is stated that the role of the teacher, who performs the evaluation and who is "the organizer and moderator of the whole work, who is a partner and associate... is very important ... and changes in the work of the teacher himself, open-mind in approach and entire perception of personality are very important" [31, pp. 31].

\section{CONCLUSION}

Based on the review and analysis of the research papers dealing with the various aspects of the reform process in secondary music education, it can be concluded that there are very few papers in our area dealing with the implementation of reform at this level of music education. The reasons for this may be different, beginning from the fact that this topic is not sufficiently interesting and provocative for music education theorists, or, on the other hand, that many perceive it as a pedagogical issue rather than a topic for music education research. Another reason for the small number of papers may be the fact that these and similar topics are mostly written by theoretical oriented authors, most often by music education methodologists, who are again relatively few as compared to other profiles working in music education. An equally important reason may be the fact that papers on this topic are most commonly found in a collection of papers from various meetings and conferences, which are often published only in hard copy and are difficult to find in electronic version. All this contributes to the fact that the works concerning the implementation of the reform interventions are not sufficiently visible to the general public, that may also be interested in these issues.

Accordingly, only research papers that are entirely available in adequate internet services were used for the analysis. Regardless of the small number of papers, it can be concluded that their topics are mainly limited to the issues related to changes in curricula, innovation in content, i.e textbooks, as well as issues of assessment and performance of secondary music students.

Bearing in mind that these are key topics related to changes in music education, it can be concluded that the authors generally note that changes have occurred in secondary music schools, but that they need to continue to develop and to be implemented in everyday 
school practice. In addition, it should be borne in mind that changes in education systems at all levels are very slow and that it takes time to study and analyze them in order to determine the effects they achieve.

Although there were evident limitations in writing this paper, first of all, a small number of papers for analysis, as well as a restriction related only to changes in the Serbian school system, the results obtained by the research may be relevant for the narrow professional public approach to music education at the secondary school level. More broadly, the analysis can be of importance as a basis for future research of this issue, especially when taking in account that the school reform process is a constant, flexible and faithful follower of social changes.

Acknowledgement: The paper is a part of the project "Enhancing professional competencies of prospective pedagogues within the framework of undergraduate academic studies of pedagogy" (360/1-16-5-01), which is carried out at the University of Nis - Faculty of Philosophy. This study was financially supported by the Ministry of Education, Science and Technological Development of the Republic of Serbia.

\section{REFERENCES}

Anđelković, S., Stanisavljević Petrović, Z., (2013), Škola i neformalni obrazovni konteksti [School and nonformal educational contexts], Geografski fakultet, Beograd.

Bogunović, B., (1997), "Motivacija učenika srednje muzičke škole" [Motivation of students of music high school], Psihološka istraživanja, no. 8, pp. 267-274.

Bogunović, B., (1998), "Motivacija postignuća kao činilac uspeha u učenju muzike" [Achievement motivation as a factor of success in learning music], Psihologija, no. 3-4, pp. 91-99.

Bogunović, B., (2006), "Tumačenje postignuća u učenju muzike i dinamička svojstva učenika” [Interpretation of achievement in music learning and dynamic characteristics of students], Nastava $i$ vaspitanje, vol. 55, no. 3, pp. 296-306

Bogunović, B., (2008), Muzički talenat i uspešnost [Musical talent and success], Institut za pedagoška istraživanja, Beograd.

Hebib, E., (2009), Škola kao sistem [School as a system], Institut za pedagogiju i andragogiju, Beograd.

Hebib, E., Spasenović, V., (2011), Školski sistem Srbije - stanje i pravci razvoja [School system of Serbia: State and directions of development], Pedagogija, vol. 66, no. 3, pp. 373-383.

Izmene Nastavnog plana i programa SS̆ za područje rada „Kultura, umetnost i javno informisanje“ [Changes in the curriculum of vocational schools in the field of work "Culture, art and public informing], Službeni glasnik Republike Srbije, (2013), br. 10/2013.

Jović Miletić, A., (2010), "Pedagoška istraživanja u muzičkoj nastavi" [Pedagogical research in teaching music], Pedagogija, vol. 65, no. 4, pp. 662-667.

Kovač Cerović, T., Levkov, Lj., (2002), Kvalitetno obrazovanje za sve - put ka razvijenom društvu [Quality education for all - the pathway to a developed society], Ministarstvo prosvete i sporta Republike Srbije, Beograd.

Marković, M., (2017), "Mogućnosti ostvarivanja inkluzije u školskom kontekstu" [Possibilities of achieving inclusion in the school system], Godišnjak za pedagogiju, vol. 2, no. 1, pp. 51-62.

Marković, M., (2018), 'Razvoj kompetencija nastavnika za inkluzivno obrazovanje" [Development of teachers' competencies for inclusive education], u: Bojan Blagojević (ur.), Mesto i uloga društveno-humanističkih nauka u savremenom svetu, Tematski zbornik radova, Knjiga 2, Filozofski fakultet, Niš.

Pekić, J., (2008), "Inteligencija i osobine ličnosti kao prediktori muzički darovitih srednjoškolaca" [Intelligence and personality traits as predictors of musically gifted high school students], Primenjena psihologija, vol. 2, br. 1, pp. 75-91.

Ratković, M., Hebib, E., Šaljić, Z., (2017), ’Inkluzija u obrazovanju kao cilj i sadržaj reformi savremenih školskih sistema" [Inclusion in education as a goal and content of reforms of contemporary school systems], Nastava $i$ vaspitanje, vol. 66, no. 3, pp. 437-450. 
Spasenović, V., Matović, N., (2015), "Pripremljenost nastavnika razredne i predmetne nastave za rad s decom sa smetnjama u razvoju" [Preparedness of elementary and middle school teachers for work with children with developmental difficulties], Nastava $i$ vaspitanje, vol. 64, no. 2, pp. 207-222.

Spasenović, V., Hebib, E., Petrović, A., (2007), "Serbia", in: W. Horner et al. (eds), The Education Systems of Europe, Springe, Dordrecht.

Stanisavljević Petrović Z., Cvetković, M., (2012), "Modernizacija školskog sistema u Srbiji” [Modernization of the school system in Serbia], Kultura polisa, vol. 9, no. 18, pp. 181-195.

Stančić, M., (2020), .Lica i naličja pravednosti u ocenjivanju [Faces and insides of fairness in evaluation], Institut za pedagogiju i andragogiju Filozofskog fakulteta, Beograd.

Stanisavljević Petrović, Z., Vidanović, D., (2012), Promene u školskom sistemu u Srbiji [Changes in the school system of Serbia], Filozofski fakultet, Niš.

Statut Muzičke škole Niš [Statute of the Music School Nis], (2013), Muzička škola, Niš, br. 02-6/375.

Stojanović, D., (2017), "(Re)konstrukcija nastavnih planova i programa predmeta Kontrapunkt u srednjoškolskom muzičkom obrazovanju - nužnost i/ili potreba?" [(Re)constuction of the curriculum of the subject Conterpoint in secondary music education - a necessity and/or a need], u: S. Marinković, S. Dodik, D. Panić Kašanski (ur.), Vlado S. Milošević: etnomuzikolog, kompozitor i pedagog, Tradicija kao inspiracija, Akademija umjetnosti u Banjoj Luci, Akademija nauka i umjetnosti Republike Srpske, Muzikološko društvo Republike Srpske, Banja Luka.

Stojanović, D., Nagorni Petrov, N., (2019), "Modifikacija kurikuluma Metodike nastave teorijskih predmeta izazov i/ili potreba" [Curriculum modification of Methods of teaching theoretical subjects - a challenge and/or a need], u: M. Milenković (ur.), Zbornik radova Balkan Art Forum 2018: Umetnost i kultura danas: obrazovanje za umetnosti i izazovi savremenosti, Fakultet umetnosti u Nišu, Niš

Stojanović, D. Zdravić Mihailović, D., (2014), "Problemi savremene nastave u srednjoj muzičkoj školi" [Problems of contemporary teaching in music high school], u: D. Žunić, M. Đurđanović (ur.), Balkan Art Forum 2013, Umetnost $i$ kultura danas, Fakultet umetnosti Univerziteta u Nišu, Niš.

Stojanović, D., (2016), "Nastavna sredstva kao prediktori školskog uspeha u muzičkom obrazovanju" [Teaching tools as predictors of school success in music education], u: S. Marinković, S. Dodik, D. Panić Kašanski (ur.), Zbornik radova Vlado S. Milošević: etnomuzikolog, kompozitor i pedagog, Tradicija kao inspiracija, Akademija umjetnosti u Banjoj Luci, Banja Luka.

Stojanović, D. Nagorni Petrov, N., Zdravić Mihailović, D., (2013), ”Holistički pristup nastavnika u procesu ocenjivanja uspešnosti studenata u muzičkom obrazovanju" [A holistic approach of teachers in the process of evaluating students' success in music education], u: D. Vidanović (ur.), Holistički pristupi u vaspitanju, Visoka škola strukovnih studija za obrazovanje vaspitača, Pirot.

Strategija razvoja obrazovanja u Srbiji do 2020. godine [Strategy for the development of education in Serbia until 2020], Službeni glasnik Republike Srbije, (2012), br. 107/2012.

Strategija razvoja stručnog obrazovanja u Republici Srbiji [Strategy for the development of the vocational education in the Republic of Serbia], Službeni glasnik Republike Srbije, (2006), br. 1/07.

Ustav Republike Srbije [Constitution of the Republic of Serbia], Službeni glasnik Republike Srbije, (2006), br. 98/2006.

Zakon o srednjem obrazovanju i vaspitanju [Law on secondary education and upbringing], Službeni glasnik Republike Srbije, (2013), br. 55/2013.

Zakon o osnovama sistema obrazovanja i vaspitanja [Law on the basis of the system of education and upbringing], Službeni glasnik Republike Srbije, (2009), br. 72/2009.

Zdravić Mihailović, D., Stojanović, D., (2016), "Razvoj kompetencija učenika u stručnom muzičkom obrazovanju" [Development od students' competencies in professional music education], u: N. Nagorni Petrov (Ur.), Balkan Art Forum 2015: Umetnost i kultura danas: Kriza u umetnosti-umetnost u krizi, Fakultet umetnosti u Nišu, Niš. 


\section{POJEDINI ASPEKTI REFORMSKIH PROMENA U SISTEMU SREDNJIH MUZIČKIH ŠKOLA- ANALIZA RELEVANTNE LITERATURE}

$U$ radu se razmatraju neki aspekti reformskih promena u srednjoškolskom muzičkom obrazovanju. Reformske promene u srednjem muzičkom obrazovanju usklađene su sa opštim tendencijama promena u školskom sistemu u Srbiji. Shodno tome, u radu se razmatraju vodeći aspekti promena koji se odnose na menjanje srednjih muzičkih škola I njihovo usklađivanje sa sličnim školama u evropskom obrazovnom prostoru.

Osnovni cilj ovog teorijskog istraživanja jeste identifikovanje značajnih aspekata promena koji se odnose na menjanje nastavnih planova i programa, inovacije u sadržajima - udžbenicima $i$ procesu ocenjivanja. U radu je korišćen kvalitativni pristup, koji se zasniva na analizi izabranih istraživačkih studija koje su objavljene nakon 2001. godine, a koje obuhvataju ključne teme koje se odnose na promene u srednjim muzičkim školama. Uprkos činjenici da je na našim prostorima malo istraživačkih radova koji su se bavili implikacijama reforme u sistemu srednjeg muzičkog obrazovanja, na osnovu analize dostupnih radova može se konstatovati da postoje koraci koji idu u susret planiranim promenama.

Ključne reči: muzičke škole, srednjoškolsko obrazovanje, reforme, nastavni planovi, inovacije, metode rada, ocenjivanje. 